ISSN 0258-7122 (Print), 2408-8293 (Online)

Bangladesh J. Agril. Res. 43(2): 333-343, June 2018

\title{
INCREASING CROPPING INTENSITY AND PRODUCTIVITY THROUGH MUNGBEAN INCLUSION IN WHEAT-FALLOW-T. AMAN RICE CROPPING PATTERN
}

\author{
M. A. H. KHAN ${ }^{1}$, N. SULTANA ${ }^{2}$, N. AKTER ${ }^{3}$ \\ M. S. ZAMAN ${ }^{4}$ AND A. K. CHOUDHURY ${ }^{5}$
}

\begin{abstract}
The experiment was conducted at the farmers' field of Bhaluka Upazilla under On-Farm Research division, Bangladesh Agricultural Research Institute, Mymensingh during 2014-15 and 2015-16 to evaluate the performance of Wheat-Mungbean-T.aman rice improved cropping pattern against a farmers cropping pattern of Wheat-Fallow-T.aman rice. The findings of the study indicated that three crops could be grown successfully in sequence in the tested site. The higher rice equivalent yield $\left(15.33 \mathrm{t} \mathrm{hd}^{-1} \mathrm{yr}^{-1}\right)$, production efficiency $\left(34.74 \mathrm{~kg} \mathrm{ha}^{-1}\right.$ day $\left.^{-1}\right)$ and land utilization index $(70.69 \%)$ were obtained from the improved cropping pattern than the farmer's one. Average gross return (Tk. $262750 \mathrm{ha}^{-1}$ ), gross margin (Tk $126204 \mathrm{ha}^{-1}$ ) and marginal benefit cost ratio (MBCR) 2.23 of the improved pattern indicate it's superiority over farmers' existing pattern. The fertility status of soil i.e. $\mathrm{pH}$, organic matter, total $\mathrm{N}$, available $\mathrm{P}, \mathrm{S}, \mathrm{Zn}$ and $\mathrm{B}$ content in soil were increased over the initial soil due to addition of mungbean biomass.Thus, inclusion of mungbean in the existing farmer's cropping pattern will improve soil health and the system productivity as a whole.
\end{abstract}

Keywords: Cropping intensity, cropping pattern, mungbean, productivity and gross return.

\section{Introduction}

Bangladesh is almost self-sufficient in rice production, other food production such as wheat, pulses, oil crops and vegetables etc. are still deficient to a large extent. Wheat is one of the major cereals in rabi season in the central and northwestern part of Bangladesh, though the largest area is still under transplanted aman rice cultivation during monsoon season. However, most of the aman rice area is covered with long duration T.aman varieties which cause a delay in wheat sowing, resulted reduce the yield. November 15 to 30 is the best time for wheat sowing, which can avoid drought and diseases at the terminal stage of growth of the crop. If short duration T.aman rice varieties mainly BRRI dhan56, BRRI dhan57 and Binadhan-16 can be transplanted instead of long duration ones then timely (November) sowing of wheat could be ensured. Most

\footnotetext{
${ }^{1 \& 2}$ Senior Scientific Officer, ${ }^{3}$ Scientific Officer, ${ }^{4 \& 5}$ Principal Scientific Officer, On-Farm Research Division, Bangladesh Agricultural Research Institute (BARI), Joudebpur, Gazipur, Bangladesh.
} 
of the farmers of Mymensingh area follow Wheat-Fallow-T.aman rice and Wheat-Jute-T.aman rice cropping pattern in $1 \%$ of the cultivated land (Kabir and Islam, 2012). Many farmers are cultivating wheat followed by T.aman rice with keep their fallow land for at least 120-130 days. There is an ample scope of introducing a short duration crop like mungbean in kharif 1 during fallow period after wheat. Mungbean is a short duration (60-70 days) leguminous high value pulse crop, which may easily be fitted in between wheat and T.aman rice in the existing cropping pattern. Mungbean contains $60 \%$ carbohydrates, $25 \%$ protein, $4 \%$ mineral and $3 \%$ vitamins (Kaul, 1982). Moreover, as a leguminous crop, it adds nitrogen in soil and improves soil health. Wheat-Mungbean-T.aman rice cropping pattern is presumably suitable for the Bhaluka soils, which requires relatively limited amount of irrigation water for wheat, mungbean and T.aman rice cultivation. However, incorporation of green manure and grain legume crops in the pattern might improve soil health (BARC, 2001). It is well known that biomass of legumes and arable crops improve soil fertility with little or no reduction in crop yields. Therefore, the experiment was undertaken to assess the feasibility of growing mungbean into Wheat-fallow-T.aman rice cropping pattern to improve soil fertility and the system productivity.

\section{Materials Methods}

The experiment was conducted at the farmers' field of Bhaluka, Mymensingh under On-Farm Research Division, Bangladesh Agricultural Research Institute, Mymensingh during 2014-15 and 2015-16.The geographical position of the area is between $24^{\circ} 38^{\prime} \mathrm{N}$ latitude and $90^{\circ} 33^{\prime} \mathrm{E}$ longitude. The meteorological data of the experimental site revealed that the highest temperature prevails in July and the lowest in December (Table 1). There is no precipitation in December. In June, the precipitation reaches its peak with an average of $436.45 \mathrm{~mm}$. Maximum rainfall was received during the months of April to September. The precipitation varies $436.45 \mathrm{~mm}$ between the driest month and wettest month. In 2014-15, monthly mean maximum $32.93\left({ }^{\circ} \mathrm{C}\right)$ and minimum $17.51\left({ }^{\circ} \mathrm{C}\right)$ air temperature and annual total rainfall $2110.70(\mathrm{~mm})$ and in 2015-16, monthly mean maximum $32.95\left({ }^{\circ} \mathrm{C}\right)$ and minimum $19.99\left({ }^{\circ} \mathrm{C}\right)$ air temperature and annual total rainfall $1895.00(\mathrm{~mm})$ were prevailing in the study area (Appendix I). However, a analysis of 10 years (2004-2013) daily climatic data indicates the average maximum temperature $\left(0.35^{\circ} \mathrm{C}\right)$, average minimum temperature $\left(0.11^{\circ} \mathrm{C}\right)$ and average temperature $\left(0.24^{\circ} \mathrm{C}\right)$ increase over 2004 (Appendix II).

The experimental site belongs to Madhupur Tracts Agro-ecological Zone (AEZ28) of Mymensingh. The land type was medium high and general soil types exist in the area of which deep red brown terrace, shallow red brown terrace and acid basin clays. The top soil are mainly strongly acidic to slightly acidic with low to medium status of organic matter, low moisture holding capacity and low fertility level. A description of nutrient status of initial soil is presented in Table 1. 
Table 1. Initial soil test values of the farmers' field at Bhaluka upazilla, Mymensingh

\begin{tabular}{l|c|c|c|c|c|c|c|c}
\hline \multirow{2}{*}{ Sample } & $\mathrm{pH}$ & $\begin{array}{c}\mathrm{OM} \\
(\%)\end{array}$ & $\begin{array}{c}\text { Total N } \\
(\%)\end{array}$ & $\begin{array}{c}\mathrm{K} \\
(\mathrm{meq} / 100 \mathrm{~g})\end{array}$ & $\mathrm{P}($ Bray $)$ & $\mathrm{S}$ & $\mathrm{Zn}$ & $\mathrm{B}$ \\
\cline { 7 - 10 } & & & & & & & $(\mu / \mathrm{g})$ & \\
Initial & 5.85 & 1.59 & 0.088 & 0.15 & 10.30 & 13.42 & 0.75 & 0.18 \\
Critical level & - & - & 0.12 & 0.12 & 7.00 & 10.00 & 0.60 & 0.20 \\
\hline
\end{tabular}

The experiment was laid out in a randomized complete block design with six dispersed replications. Two cropping pattern viz., improved pattern and farmers' existing pattern were the treatments variables of the experiment. The unit plot size was $1000-1200 \mathrm{~m}^{2}$. Fertilizer management was followed by FRG (2012) and intercultural operations like weeding, mulching, irrigation and pest management were done to support the normal growth of the crops. Wheat var. BARI Gom-26, mungbean var. BARI Mung- 6 and rice var. BRRI dhan 57 were used in improved pattern and wheat var. BARI Gom-26 and rice var. Horidhan were used in the farmers' pattern. Wheat was the first crop of the sequence. In improved pattern, BARI Gom-26 was seeded as broadcast at @ $120 \mathrm{~kg} \mathrm{ha}^{-1}$ during 26-29 November, 2014 and 20-26 November 2015 and harvested during 15-17 March 2015 and 10-15 March 2016. In the farmers' pattern, BARI Gom-26 was seeded as broadcast at @ $120 \mathrm{~kg} \mathrm{ha}^{-1}$ during 04-07 December 2014 and 24-27 November 2015, and harvested during 21-24 March 2015 and 14-18 March 2016. Mungbean was the second crop of the sequence which was seeded as broadcast @ $30 \mathrm{~kg} \mathrm{ha}^{-1}$ during 5-10 April 2015 and 26-30 March 2016, and harvested during 15-20 June 2015 and 10-16 June 2016, respectively. After harvest of mungbean pods, the plants were incorporated into soil. The third crop was T.aman rice was transplanted, 25-30 days old seedlings with $20 \mathrm{~cm} \times 15 \mathrm{~cm}$ spacing during 8-10 August, 2015 and 12-16 August 2016. The crop was harvested during 24-27 October, 2015 and 26-29 October 2016. In farmers'pattern, 30-35 days old seedlings of T.aman rice were transplanted with a $20 \mathrm{~cm} \times 15 \mathrm{~cm}$ spacing during 10-15 August, 2015 and 08-13 August 2016, and harvested during 25-28 November, 2015 and 15-20 November 2016. In T.aman rice, fertilizer management and intercultural operations like weeding, mulching, irrigation and pest management were done according to BRRI (2013). Yield data were collected from $4 \mathrm{~m} \times 3 \mathrm{~m}$ area of each plot. Grains and straw were sun dried and weighed adjusting at 14, 12 and $10 \%$ moisture content for T.aman rice, wheat and mungbean, respectively. Agronomic performance like field duration, rice equivalent yield (REY), production efficiency and land utilization index of cropping patterns were calculated as follows.

Rice Equivalent Yield (REY): For comparison between crop sequences, the yield of every crop was converted into rice equivalent yield. Rice equivalent yield (REY) was computed as yield of individual crop multiplied by market price of that crop divided by market price of rice (Verma and Modgal, 1983). 
Rice equivalent yield $\left(\right.$ tha $\left.^{-1} \mathrm{yr}^{-1}\right)=\frac{\text { Yieldof individuatrop } \times \text { market priceof that crop }}{\text { market priceof rice }}$

Production efficiency: Production efficiency value in terms of $\mathrm{kgha}^{-1} \mathrm{day}^{-1}$ was calculated by total main product in a cropping pattern divided by total duration of crops in that pattern (Tomar and Tiwari, 1990).

Production Efficiency $\left(\mathrm{kgha}^{-1}\right.$ day $\left.^{-1}\right)=\frac{\sum \mathrm{Y}_{\mathrm{i}}}{\sum \mathrm{d}_{\mathrm{i}}}$

Where, $Y_{i}=$ Yield $(\mathrm{kg})$ of $\mathrm{i}^{\text {th }}$ crop, $\mathrm{d}_{\mathrm{i}}=$ Duration (day) of $\mathrm{i}^{\text {th }}$ crop of the pattern and $\mathrm{i}=1,2,3$

Land utilization index (LUI): It was worked-out by taking total duration of crops in an individual cropping pattern divided by 365 days (Rahman et. al. 1989). It was calculated by the following formula:

Land Utilization Index $(\%)=\frac{\mathrm{d}_{1}+\mathrm{d}_{2}+\mathrm{d}_{3}}{365} \times 100$

Where $d_{1}, d_{2}$, and $d_{3}$ the duration of $1^{\text {st }}, 2^{\text {nd }}$ and $3^{\text {rd }}$ crop of the pattern

Economic analysis was done on the basis of prevailing market price of the commodities. The marginal benefit cost ratio (MBCR) of the farmer's prevalent pattern and any replacement for it can be computed as the marginal value product ((MVP) over the marginal value cost (MVC). The marginal of prevalent pattern (F) and any potential replacement (E) which was computed following CIMMYT (1988).

Marginal Benefit Cost Ratio $(\mathrm{MBCR})=\frac{\text { Gross return }(\mathrm{E})-\text { Gross Return }(\mathrm{F})}{\mathrm{TVC}(\mathrm{E})-\mathrm{TVC}(\mathrm{F})}=\frac{\mathrm{MVP}}{\mathrm{MVC}}$

Where $\mathrm{TVC}=$ Total Variable Cost

\section{Results and Discussion}

Results of the two years study of improved cropping pattern (Wheat-MungbeanT.aman rice) and farmer's existing pattern (Wheat-Fallow-T.aman rice) are presented in Table 2-5.

\section{Grain and By-Product Yield}

Grain yields of wheat were 3.50 and $3.65 \mathrm{t} \mathrm{ha}^{-1}$ and straw yields were 3.65 and $3.90 \mathrm{t} \mathrm{ha}^{-1}$ in two consecutive years, respectively. Wheat grain yield decreased by $4 \%$ in the $1^{\text {st }}$ year probably due to late sown (6 days) than that in the $2^{\text {nd }}$ year. Two years average grain and straw yields of wheat were 3.58 and $3.78 \mathrm{t} \mathrm{ha}^{-1}$. Seed yield of mungbean was $1.16 \mathrm{t} \mathrm{ha}^{-1}$ in the $1^{\text {st }}$ year and $1.29 \mathrm{t} \mathrm{ha}^{-1}$ in the $2^{\text {nd }}$ year. Mean seed and biomass yields of mungbean were 1.23 and $2.31 \mathrm{t} \mathrm{ha-}^{-1}$, 
respectively. The yield of mungbean was also satisfactory in the $1^{\text {st }}$ year but produced $10 \%$ less yield than the $2^{\text {nd }}$ year due to late sown mungbean (10 days earlier in the $2^{\text {nd }}$ year). These results are in agreement with Sarker et. al. (2014) who reported that late sown mungbean produced lower yield than that of sown only 5-7 days earlier. Grain yields of T.aman rice were 4.10 and $4.23 \mathrm{t} \mathrm{ha}^{-1}$ in the two successive years. Mean grain and straw yields of T.aman rice were 4.17 and $4.48 \mathrm{t} \mathrm{ha}^{-1}$. It was revealed that all the component crops under improved pattern (Wheat-Mungbean-T.aman rice) gave higher grain yield as well as by-product yield (Table 2). Average yield of wheat and T.aman rice in improved pattern increased by 9 and $15 \%$ over farmers' practice (FP). The yield of improved pattern was higher presumably due to change of variety with improved production technologies and timely sowing of the component crops. Improved pattern produced higher by-product yield $\left(10.56 \mathrm{t} \mathrm{ha}^{-1}\right)$ over farmers' practice $\left(7.80 \mathrm{t} \mathrm{ha}^{-1}\right)$ which was $35 \%$ higher due to change of variety with improved management practices and inclusion of mungbean. Farmers' pattern produced less yields than the improved one mostly due to use of imbalance fertilizers and poor management practices.

Farmers' cropping pattern Wheat-Fallow-T.aman needed 205 and 207 days field duration in the $1^{\text {st }}$ and $2^{\text {nd }}$ year. Contrary, total field duration of the improved pattern Wheat-Mungbean-T.amanwas 256 and 260 days (excluding seedling age of rice) to complete the cycle in the $1^{\text {st }}$ and $2^{\text {nd }}$ year, respectively (Table 2 ). Thus, the turn-around period of 158-160 days was utilized in the farmers existing pattern. Result indicated that mungbean could be easily fitted in Wheat-Rice cropping pattern with an average of 108 days turn-around time in a year.

Table 2. Yield of different crops under improved cropping pattern (IP) and farmers' existing cropping pattern (FP) at Bhaluka upazilla, Mymensingh during 2014-15 and 2015-16

\begin{tabular}{c|c|c|c|c|c|c}
\hline \multirow{2}{*}{ Parameters } & \multirow{2}{*}{ Years } & \multicolumn{3}{|c|}{$\begin{array}{c}\text { Improved Cropping Pattern } \\
\text { (IP) }\end{array}$} & $\begin{array}{c}\text { Farmers' Cropping Pattern } \\
\text { (FP) }\end{array}$ \\
\cline { 3 - 7 } & & Wheat & Mungbean & T.aman & Wheat & T.aman \\
\hline Grain yield & $2014-15$ & 3.50 & 1.16 & 4.10 & 3.10 & 3.52 \\
$\left(\mathrm{t} \mathrm{ha}^{-1}\right)$ & $2015-16$ & 3.65 & 1.29 & 4.23 & 3.45 & 3.75 \\
& Average & 3.58 & 1.23 & 4.17 & 3.28 & 3.64 \\
\hline Straw yield & $2014-15$ & 3.65 & 2.23 & 4.40 & 3.29 & 4.20 \\
$\left(\mathrm{t} \mathrm{ha}^{-1}\right)$ & $2015-16$ & 3.90 & 2.38 & 4.56 & 3.48 & 4.62 \\
& Average & 3.78 & 2.31 & 4.48 & 3.39 & 4.41 \\
\hline Duration & $2014-15$ & 108 & 70 & 78 & 109 & 96 \\
$($ days) & $2015-16$ & 109 & 76 & 75 & 109 & 98 \\
& Average & 109 & 73 & 77 & 109 & 97 \\
\hline \multirow{2}{*}{ Turnaround } & $2014-15$ & 32 & 22 & 55 & 20 & 140 \\
time (days) & $2015-16$ & 25 & 17 & 63 & 17 & 141 \\
& Average & 29 & 20 & 59 & 19 & 141 \\
\hline
\end{tabular}




\section{Rice Equivalent Yield (REY)}

Total productivity of improved and farmers' cropping patterns were evaluated in terms of rice equivalent yield (REY) and it was calculated from yield of component crops. Improved cropping pattern produced higher mean rice equivalent yield $\left(15.33\right.$ tha $\left.^{-1} \mathrm{yr}^{-1}\right)$ over farmers' $\left(8.75\right.$ tha $\left.^{-1} \mathrm{yr}^{-1}\right)$ existing pattern (Table 3). Inclusion of mungbean in kharif-1 season in improved cropping pattern increased REY of $75 \%$ compared to farmers' one. These results are in agreement with that of Mondal et al. (2015) who reported that total productivity increased by $67 \%$ over farmers, practice due to inclusion of a third crop (mungbean) in the pattern.

\section{Production Efficiency (PE)}

Maximum production efficiency (34.74) in terms of $\mathrm{kgha}^{-1} \mathrm{day}^{-1}$ was obtained from improved pattern and slightly lower (33.54) in the farmers' existing pattern (Table 3). Production efficiency in improved cropping pattern increased by 3.57 kgha $^{-1}$ day $^{-1}$ over farmers' practice which might be due to inclusion of an additional mungbean crop with modern varieties and improved management practices.

\section{Land Utilization Index (LUI)}

Land utilization index is the effective use of land in a cropping year, which mostly depends on crop duration. Land utilization index (LUI) indicated that improved pattern used the land for $70.69 \%$ period of the year, whereas farmers' pattern used the land for $56.44 \%$ period of the year (Table 3). Land use efficiency was $25.25 \%$ higher in improved pattern than farmers' practice, mostly because the improved pattern occupied the field for longer duration (259 days), than the farmers' pattern (206 days) in a year. As a result labour utilization could be more in the improved cropping pattern than existing one.

Table 3. Rice equivalent yield, production efficiency and land utilization index of improved pattern and farmers' existing pattern at Bhaluka, Mymensingh (average of 2014-15 and 2015-16)

\begin{tabular}{c|c|c|c}
\hline Cropping Pattern & $\begin{array}{c}\text { REY } \\
\left(\mathrm{t} \mathrm{ha}^{-1} \mathrm{yr}^{-1}\right)\end{array}$ & $\begin{array}{c}\text { PE } \\
\left(\mathrm{kg} \mathrm{ha}^{-1} \mathrm{day}^{-1}\right)\end{array}$ & LUI (\%) \\
\hline Wheat-Mungbean-T.aman (IP) & 15.33 & 34.74 & 70.69 \\
Wheat-Fallow-T.aman (FP) & 8.75 & 33.54 & 56.44 \\
Increased (\%) & 75.20 & 3.57 & 25.25 \\
\hline
\end{tabular}

Note: REY=Rice equivalent yield, PE=production efficiency and LUI= land utilization index 


\section{Soil fertility status}

The status of soil $\mathrm{pH}$, organic matter, total $\mathrm{N}$, available $\mathrm{P}, \mathrm{K}, \mathrm{S}, \mathrm{Zn}$ and $\mathrm{B}$ in initial soil as well as after completion of two cropping cycle of WheatMungbean-T.aman cropping pattern is shown in Table 4. Initially the $\mathrm{pH}$ of the soil was 5.85 but after completion of two cropping cycle the soil $\mathrm{pH}$ slightly increased to near 5.88. It was also found that the fertility status of soil i.e. organic matter, total $\mathrm{N}$, available $\mathrm{P}, \mathrm{S}, \mathrm{Zn}$ and B contents in soil were increased slightly over the initial soil due to addition of mungbean biomass. However, $\mathrm{K}$ in the improve pattern tended to be lower than the farmers one, which indicated to add more K to the soil to improve K content. Rao and Bhardwaj (1980) conclusively proved that pulses receiving optimum fertilizer, especially $\mathrm{P}$, had more pronounced residual effect both in terms of $\mathrm{N}$ and $\mathrm{P}$ on the succeeding cereals.

Table 4. Effect of mungbean inclusion in Wheat-Fallow-T.aman rice cropping pattern on soil fertility status of the farmers' field of Bhaluka upazilla, Mymensingh during 2014-15 and 2015-16

\begin{tabular}{|c|c|c|c|c|c|c|c|c|c|c|}
\hline \multirow[t]{2}{*}{ Sample } & \multirow{2}{*}{$\begin{array}{l}\text { Land } \\
\text { type }\end{array}$} & \multirow{2}{*}{$\begin{array}{l}\text { Rainfed/ } \\
\text { Irrigated }\end{array}$} & \multirow[t]{2}{*}{$\mathrm{pH}$} & \multirow{2}{*}{$\begin{array}{l}\mathrm{OM} \\
(\%)\end{array}$} & \multirow{2}{*}{$\begin{array}{l}\text { Total } \\
\mathrm{N}(\%)\end{array}$} & \multirow{2}{*}{$\begin{array}{c}\mathrm{K} \\
(\mathrm{meq} / \\
100 \mathrm{~g})\end{array}$} & $\begin{array}{c}\mathrm{P} \\
\text { (Bray) }\end{array}$ & $S$ & $\mathrm{Zn}$ & B \\
\hline & & & & & & & \multicolumn{4}{|c|}{$(\mu \mathrm{g} / \mathrm{g})$} \\
\hline Initial & MHL & Irrigated & 5.85 & 1.59 & $\begin{array}{l}0.088 \\
(\mathrm{VL})\end{array}$ & $\begin{array}{l}0.15 \\
(\mathrm{~L})\end{array}$ & $\begin{array}{c}10.30 \\
(\mathrm{~L})\end{array}$ & $\begin{array}{c}13.42 \\
(\mathrm{~L})\end{array}$ & $\begin{array}{c}0.75 \\
(\mathrm{~L})\end{array}$ & $\begin{array}{r}0.18 \\
(\mathrm{~L})\end{array}$ \\
\hline Final & MHL & Irrigated & 5.88 & 1.62 & $\begin{array}{l}0.091 \\
(\mathrm{~L})\end{array}$ & $\begin{array}{r}0.12 \\
(\mathrm{~L})\end{array}$ & $\begin{array}{c}10.57 \\
(\mathrm{M})\end{array}$ & $\begin{array}{c}13.51 \\
(\mathrm{~L})\end{array}$ & $\begin{array}{c}0.77 \\
(\mathrm{~L})\end{array}$ & $\begin{array}{c}0.21 \\
(\mathrm{~L})\end{array}$ \\
\hline
\end{tabular}

Note: $\mathrm{MHL}=$ Medium high land, $\mathrm{VL}=$ Very low and $\mathrm{L}=$ Low

\section{Cost and return analysis}

The economic analysis as shown in Table 5 indicated the higher return of the improved cropping pattern (Wheat-Mungbean-T.aman) than the farmers' pattern (Wheat-Fallow-T.aman). Average gross return of the improved pattern was Tk.262750 ha- ${ }^{-1}$ which was $72 \%$ higher over farmers' pattern. Mean variable cost was lower in farmers' pattern (Tk. $87420 \mathrm{ha}^{-1}$ ) than that in the improved pattern (Tk. $136546 \mathrm{ha}^{-1}$ ) which was probably due to inclusion of mungbean in the pattern as well as management practices. Average gross margin was substantially higher in the improved pattern (Tk. 1,26,204 ha-1) than farmers' pattern (Tk. $\left.65,780 \mathrm{ha}^{-1}\right)$. The higher gross margin of the improved pattern was achieved mainly due to higher yield advantages of the component crops. Additional gross margin (92\%) was achieved by adding $56 \%$ extra cost in the improved pattern. These findings are supported by Sarker et al. (2014) who reported that among the six patterns, Wheat-Mungbean-T.aman rice produced the higher economic benefit in terms of BCR. Mean marginal benefit cost ratio (MBCR) was found 2.23 which further indicated the superiority of the improved pattern over the farmers' one. Thus, inclusion of mungbean in the existing pattern might be agronomically suitable and economically profitable for the farmers' in the study site. 
Table 5. Cost and return analysis of improved cropping pattern and farmer's existing pattern at Bhaluka upazilla, Mymensingh (average of 2014-15 and 2015-16)

\begin{tabular}{l|c|c|c|c}
\hline \multicolumn{1}{c|}{ Cropping pattern } & $\begin{array}{c}\text { Gross return } \\
\left(\mathrm{Tk} \mathrm{ha}^{-1}\right)\end{array}$ & $\begin{array}{c}\text { Total } \\
\text { variable cost } \\
\left(\mathrm{Tk} \mathrm{ha}^{-1}\right)\end{array}$ & $\begin{array}{c}\text { Gross } \\
\text { margin } \\
\left(\mathrm{Tk} \mathrm{ha}^{-1}\right)\end{array}$ & MBCR \\
\hline Wheat-Mungbean-T.aman (IP) & $2,62,750$ & $1,36,546$ & $1,26,204$ & 2.23 \\
Wheat-Fallow-T.aman (FP) & $1,53,200$ & 87,420 & 65,780 & -- \\
Increased over FP (\%) & 71.50 & 56.19 & 91.86 & 1.23 \\
\hline
\end{tabular}

Output Price: Wheat $=T k 25.00 \mathrm{~kg}^{-1}$, T.aman $=$ Tk.16 kg-1 Mungbean $=T k .70 \mathrm{~kg}^{-1}$, and Straw $=$ Tk. $2 \mathrm{~kg}^{-1}$.

\section{Apparent soil nutrient balance}

Total N, P, K and S uptake by different crops at the farmer's field are presented in Fig.1. The partial net balance of $\mathrm{N}$ was negative in both the patterns and ranged from -93 to $-211 \mathrm{kgha}^{-1}$. Nitrogen replenishment through chemical fertilizer and organic matter addition either singly or in combination was not enough to balance $\mathrm{N}$ removal by crops presumably due to substantial loss of the applied $\mathrm{N}$ from the soil. The $\mathrm{P}$ balance was favourable as expected due to individual crop basis fertilization. Excess amount of $\mathrm{P}$ accumulated in the soil and positive effect of $\mathrm{P}$ was reflected in the improved pattern. In farmers' pattern, $\mathrm{P}$ balance was also positive. However, the partial net balance of $\mathrm{K}$ was negative and ranged from -65 to $-96 \mathrm{kgha}^{-1}$. This may lead to $\mathrm{K}$ depletion in the long run. There was a positive balance of $S$ in both the patterns and ranged from 6 to 33 $\mathrm{kgha}^{-1}$. These results are supported by the reports of Khan et al. (2006).

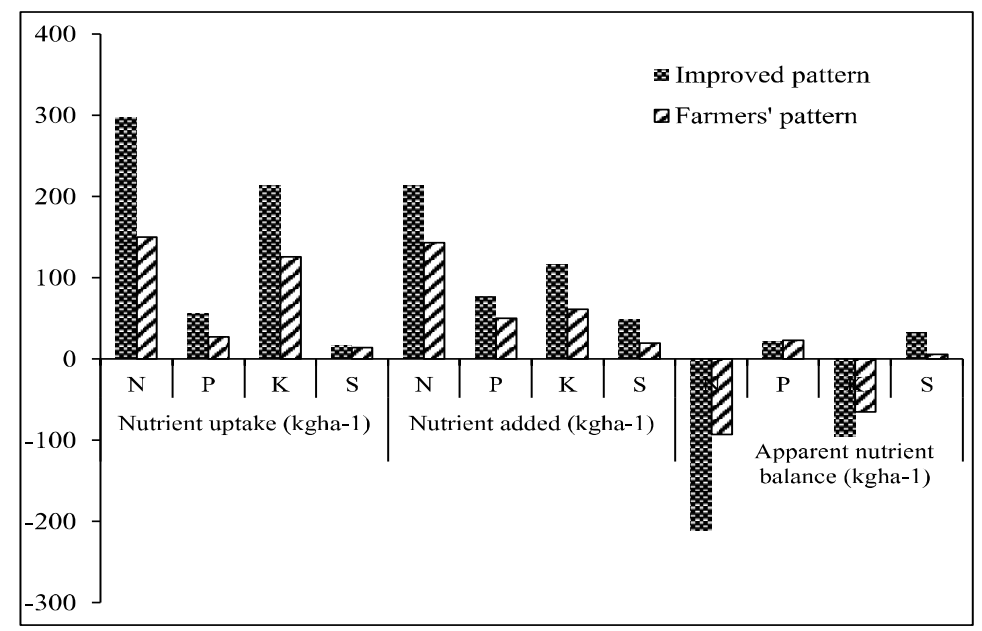

Fig 1. Effect of improved pattern and farmers' pattern on soil nutrient balance at Bhaluka, Mymensingh. 


\section{Conclusion}

Results of the two years trial clearly indicated that Wheat (Var. BARI Gom-26)Mungbean (Var. BARI Mung-6)-T.aman (Var. BRRI dhan57) cropping pattern was more productive and profitable than the farmers existing pattern Wheat (Var. BARI Gom-26)-Fallow-T.aman (Var. Haridhan). Thus, mungbean can be successfully accommodated in the existing farmers' pattern with total crop duration (259 days) in Bhaluka upazilla of Mymensingh district to increase cropping intensity and system productivity with profitability. Furthermore, through this cropping pattern the soil health may be improved and the farmers could cultivated year round crop successfully and creates employment opportunity of labour forces.

\section{Acknowledgement}

Authors are grateful to Ministry of Environment and Forest, Peoples Republic of Bangladesh for a research grant through Climate Change Trust Fund to OFRD, BARI for developed sustainable crop management technologies for drought and saline prone areas of Bangladesh.

\section{References}

BARC (Bangladesh Agricultural Research Council). 2001.Impact of land degradation of Bangladesh: A changing Scenario in agricultural land use. Bangladesh Agricultural Research Council, Farmgate, Dhaka. 39-102 Pp.

BRRI (Bangladesh Rice Research Institute). 2013. Modern Rice Cultivation, $17^{\text {th }}$ Edition, Bangladesh Rice Research Institute, Joydebpur, Gazipur-1701.

CIMMYT (International Maize and Wheat Improvement Centre). 1988. Agronomic Data to Farmer Recommendation: An Economic Training Manual. International Maize and Wheat Improvement Centre, Mexico, D. F. P. 79.

FRG. 2012. Fertilizer Recommendation Guide, Bangladesh Agricultural Research Council (BARC), Farmgate, Dhaka-1215. P. 274.

Kabir, M. J. and M. Islam. 2012. Study on agronomically and economically dominant cropping patterns in some selected areas of Barisal district. Bangladesh J. Agril. Res., 37 (1): 55-65.

Kaul, A. 1982. Pulses in Bangladesh. Bangladesh Agricultural Research Council (BARC), Farmgate, Dhaka. P. 27.

Khan, M. A. H., M. M. H. Khurram, D. A. Chowdhury, M. A. Quayyum and M. F. Islam. 2006. Integrated nutrient management in Wheat-Jute-T.aman rice cropping system. Bangladesh J. Agril. Res. 31 (2): 249-257.

Mondal, R. I., F. Begum, M. A. Aziz and S. H. Sharif. 2015. Crop sequences for increasing cropping intensity and productivity. SAARC J. Agri. 13 (1): 135-147.

Rahman, M. M., M. H. Khan, R. N. Mallick and R. E. Hudgens. 1989. Guidelinesfor Farming Systems Research Methodology. Bangladesh Agricultural Research Council, Farmgate, Dhaka-1215. 
Rao, J. V. and R. B. L. Bhardwaj. 1980. Influence of residual fertility on green gram in intensive cropping system. Indian J. Agron.25: 97-101.

Sarker, M. A. Z., M. A. Alam, A. Hossain and M. A. Mannaf. 2014. Agro-Economic performance of crop diversification in Rice based cropping systems of Northwest Bangladesh. Agriculture, Forestry and Fisheries. 3(4):26--270.

Tomer, S. S. and A. S. Tiwari. 1990. Production potential and economics of different crop sequences. Indian J. Agron. 35 (1\&2): 30-35.

Verma, S. P. and S. C. Modgal. 1983. Production potential and economics of fertilizer application as resources constraints in maize, wheat crop sequence. Himachal $J$. Agric. Res.9 (2):89-92. 
Appendix I. Monthly maximum, minimum and mean air temperature $\left({ }^{\circ} \mathrm{C}\right)$ and monthly total rainfall (mm) of Mymensingh during September 2014 to August 2016

\begin{tabular}{l|c|c|c|c|c|c|c|c}
\hline \multirow{2}{*}{$\begin{array}{c}\text { Month/ } \\
\text { Year }\end{array}$} & \multicolumn{3}{|c}{$2014-15$} & \multicolumn{3}{c|}{$2015-16$} & \multicolumn{2}{c}{$\begin{array}{c}\text { Monthly total } \\
\text { rainfall (mm) }\end{array}$} \\
\cline { 2 - 9 } & Max. & Mini. & Mean & Max. & Mini. & Mean & $2014-15$ & $2015-16$ \\
\hline September & 35.00 & 23.00 & 29.00 & 35.00 & 24.00 & 30.40 & 394.50 & 287.50 \\
October & 35.00 & 18.50 & 26.80 & 34.00 & 19.00 & 27.00 & 15.30 & 78.00 \\
November & 33.40 & 13.70 & 23.60 & 33.69 & 15.00 & 23.60 & 0.00 & 4.30 \\
December & 28.70 & 9.80 & 19.30 & 28.50 & 9.00 & 18.80 & 0.00 & 0.00 \\
January & 24.70 & 10.00 & 18.90 & 24.90 & 12.02 & 17.99 & 15.20 & 18.20 \\
February & 27.20 & 11.00 & 20.60 & 27.84 & 16.84 & 22.34 & 19.60 & 8.40 \\
March & 35.00 & 13.50 & 24.30 & 34.09 & 20.16 & 26.39 & 0.70 & 104.80 \\
April & 34.70 & 18.60 & 26.70 & 34.69 & 24.30 & 28.40 & 206.50 & 53.20 \\
May & 35.50 & 20.50 & 28.00 & 35.40 & 22.15 & 27.90 & 203.60 & 331.10 \\
June & 35.60 & 22.50 & 29.10 & 35.74 & 23.94 & 28.50 & 484.10 & 388.80 \\
July & 35.70 & 24.40 & 30.10 & 36.70 & 26.53 & 29.14 & 387.90 & 523.10 \\
August & 34.60 & 24.60 & 29.60 & 34.90 & 26.88 & 30.04 & 383.30 & 97.60 \\
Annual & $\mathbf{3 2 . 9 3}$ & $\mathbf{1 7 . 5 1}$ & $\mathbf{2 5 . 5 0}$ & $\mathbf{3 2 . 9 5}$ & $\mathbf{1 9 . 9 9}$ & $\mathbf{2 5 . 8 8}$ & $\mathbf{2 1 1 0 . 7 0}$ & $\mathbf{1 8 9 5 . 0 0}$ \\
\hline
\end{tabular}

Appendix II. Yearly maximum, minimum and average air temperature $\left({ }^{\circ} \mathrm{C}\right)$ rainfall (mm) of Mymensingh during 2004 to 2013

\begin{tabular}{c|c|c|c|c|c}
\hline Year & $\begin{array}{c}\text { Maximum } \\
\left({ }^{\circ} \mathrm{C}\right)\end{array}$ & $\begin{array}{c}\text { Minimum } \\
\left({ }^{\circ} \mathrm{C}\right)\end{array}$ & $\begin{array}{c}\text { Average } \\
\left({ }^{\circ} \mathrm{C}\right)\end{array}$ & $\begin{array}{c}\text { Temperature change } \\
\left({ }^{\circ} \mathrm{C} / \text { year }\right) \text { over } 2004\end{array}$ & $\begin{array}{c}\text { Yearly total } \\
\text { rainfall }(\mathrm{mm})\end{array}$ \\
\hline 2004 & 29.54 & 20.97 & 25.25 & 0.00 & 2563.50 \\
2005 & 29.63 & 21.16 & 25.39 & 0.23 & 2690.40 \\
2006 & 30.12 & 21.28 & 25.70 & 0.45 & 2016.20 \\
2007 & 29.57 & 20.89 & 25.23 & -0.02 & 2779.40 \\
2008 & 29.62 & 21.17 & 25.39 & 0.14 & 2202.90 \\
2009 & 30.46 & 21.28 & 25.87 & 0.62 & 1658.30 \\
2010 & 30.26 & 21.40 & 25.83 & 0.58 & 2059.70 \\
2011 & 29.66 & 20.82 & 25.24 & -0.01 & 2144.80 \\
2012 & 29.94 & 20.94 & 25.44 & 0.19 & 1521.10 \\
2013 & 30.10 & 20.90 & 25.60 & 0.35 & 1660.50 \\
Average & $\mathbf{2 9 . 8 9}$ & $\mathbf{2 1 . 0 8}$ & $\mathbf{2 5 . 4 9}$ & $\mathbf{0 . 2 5 3}$ & $\mathbf{2 1 2 9 . 6 8}$ \\
\hline
\end{tabular}


